\title{
Measurement of the sperm binding capacity of the mouse zona pellucida and its use in the estimation of anti-zona antibody titres
}

\author{
R. J. Aitken and D. W. Richardson \\ M.R.C. Unit of Reproductive Biology, Centre for Reproductive Biology, 37 Chalmers Street, \\ Edinburgh EH3 $9 E$ W, U.K.
}

\begin{abstract}
Summary. Conditions have been defined under which the sperm binding capacity of the mouse zona pellucida can be measured. As a measure of the concentration of anti-zona antibodies the inhibition of sperm binding appears to be both repeatable and sensitive. Using this technique anti-zona antibody titres were monitored in 6 rats actively immunized with extracts of mouse ovarian tissue. These animals exhibited a rapid rise in anti-zona antibody titre following the induction of immunity, and an associated significant $(P<0.05)$ decline in their fertility, both in relation to the proportions of animals exhibiting fertile matings and of matings resulting in conception. Three of the animals exhibited permanent sterility despite repeated exposure to fertile males.
\end{abstract}

\section{Introduction}

The binding of spermatozoa to the zona pellucida during the initial stages of fertilization is thought to be mediated by specific receptor sites on the sperm plasma membrane and on the zona surface (reviews by Gwatkin, 1977; Aitken \& Richardson, 1980). Little is known about the nature of these receptor sites, although in the hamster the receptor-for-spermatozoa in the zona pellucida has been shown to be sensitive to trypsin, chymotrypsin and the trypsin-like acrosin preparations from hamster, ram and boar spermatozoa (Hartmann \& Gwatkin, 1971; Gwatkin, Wudi, Hartree \& Fink, 1977b; Gwatkin, 1977). In the mouse a protein (ZP3) with a molecular weight of about 83000 has been isolated from solubilized zona preparations and exhibits properties consistent with a sperm receptor (Bleil \& Wassarman, 1980a). These putative zona receptors are thought to play a role in the physiological block to polyspermy; the dehiscence of cortical granules from the surface of hamster, rat or mouse oocytes induces a post-penetration change in the affinity of the zona pellucida for spermatozoa by a reduction in the number or availability of sperm receptor sites (Austin \& Braden, 1956; Inoue \& Wolf, 1975; Gwatkin, 1977; Aitken \& Richardson, 1980).

The binding of spermatozoa to sperm receptors in the zona pellucida can also be inhibited in vivo and in vitro by non-physiological means, as when unfertilized hamster (Shivers, Dudkiewicz, Franklin \& Fussell, 1972; Oikawa \& Yanagimachi, 1975), mouse (Jilek \& Pavlok, 1975; Tsunoda \& Chang, 1976a, 1977) or rat (Tsunoda \& Chang, 1976b) eggs are exposed to antibodies to the zona pellucida. This observation led to the suggestion that the zona pellucida might be a suitable target for an immunological approach to contraception.

To study the influence of anti-zona antibodies, cortical granule exudates and enzymes on the sperm-egg association in vitro it is necessary to establish conditions under which the sperm 
binding capacity of the zona pellucida can be measured. This study set out to define such conditions, and, in addition, to examine the feasibility of using the inhibition of sperm binding to the zona pellucida as a criterion for estimating anti-zona antibody titres in animals actively immunized with heterologous ovarian extracts.

\section{Materials and Methods}

\section{Preparation of gametes}

Oocytes were obtained by inducing female mice of the random-bred $Q$ strain to superovulate in response to 5 i.u. PMSG (Folligon or Gestyl: Organon) followed $48 \mathrm{~h}$ later by 5 i.u. hCG (Chorulon or Pregnyl: Organon). The cumulus masses were recovered from the tubal ampullae 15-18 h after hCG administration and released into glutamine-free Hepes-buffered medium 199 (Flow Laboratories, Irvine, U.K.) supplemented with $0.003 \%$ pyruvate, $0.3 \%$ BSA and $100 \mu \mathrm{g}$ gentomycin (Flow Laboratories)/ml (Gwatkin, 1977). The cumulus cells were then dispersed by exposing the eggs to $0.1 \%$ hyaluronidase (Sigma). The eggs were then washed 3 times in the above medium and maintained at $37^{\circ} \mathrm{C}$ for the remainder of the experiment.

Epididymides were removed from 10-14-week-old mice of the random-bred $Q$ strain and the caudae were cut into 3 or 4 segments to release spermatozoa into supplemented Hepes-buffered medium 199 , maintained at $37^{\circ} \mathrm{C}$. After $5 \mathrm{~min}$ the epididymal segments were removed and a sample of the sperm suspension was diluted 1 in 20 with sperm immobilization fiuid (5\% $\mathrm{NaHCO}_{3}$ in $1 \%$ formalin) before counting in an improved Neubauer haemocytometer. The spermatozoa were subsequently diluted to a concentration of $2 \times 10^{6}$ and incubated for $1 \mathrm{~h}$ at $37^{\circ} \mathrm{C}$ before the addition of cumulus-free ova.

\section{Sperm binding assay}

For the sperm binding assay, 620 - $\mu$ l droplets of the sperm suspension were dispensed into sterile Petri dishes (Falcon), covered with paraffin oil and maintained at $37^{\circ} \mathrm{C}$. In an initial experiment cumulus-free ova were transferred to the sperm suspensions (1-3 eggs per drop) and incubated for 10-120 min. Eggs were removed at various times and taken through 3 successive washes in Hepes-buffered supplemented medium 199, as recommended by Hartmann, Gwatkin \& Hutchison (1972), using hand-drawn glass micropipettes with an internal diameter of about $175 \mu \mathrm{m}$. The eggs were then transferred in about $5 \mu \mathrm{l}$ of fluid to the centre of an acetone-cleaned dry slide and covered with a $22 \times 22 \mathrm{~mm}$ coverslip, mounted on 4 paraffin wax supports. The eggs were subsequently compressed to a depth of about $50 \mu \mathrm{m}$ on the stage of a Leitz Orthodox II microscope at $\times 40$ magnification. The ova were photographed at a magnification of $\times 250$ and the numbers of spermatozoa bound per $\mathrm{mm}^{2}$ of zona surface were calculated from the photographic prints (Pl. 1, Fig. 1). The number of spermatozoa associating with the zona surface increased rapidly over the first $30 \mathrm{~min}$ and then remained constant for the next $30 \mathrm{~min}$ before exhibiting a sudden decline about $65 \mathrm{~min}$ after the addition of cumulus-free ova to the sperm suspension (Text-fig. 1). All subsequent determinations of the sperm binding capacity of the zona pellucida were therefore carried out $50 \mathrm{~min}$ after exposure of the eggs to spermatozoa.

\section{Immunoprecipitation and immunofluorescence technique}

Cumulus-free mouse ova were incubated in 20 - $\mu$ l droplets of antiserum (see below) under paraffin oil for $30 \mathrm{~min}$ at $37^{\circ} \mathrm{C}$, and then washed 4 times in medium 199, allowing at least 5 min in each of the last two washes. The eggs were then examined under dark-field illumination for the presence of a precipitation layer on the outer surface of the zona pellucida (Pl. 1, Fig. 2) or incubated for a further $30 \mathrm{~min}$ in a $1: 10$ dilution of fluorescein-labelled antibody directed against 


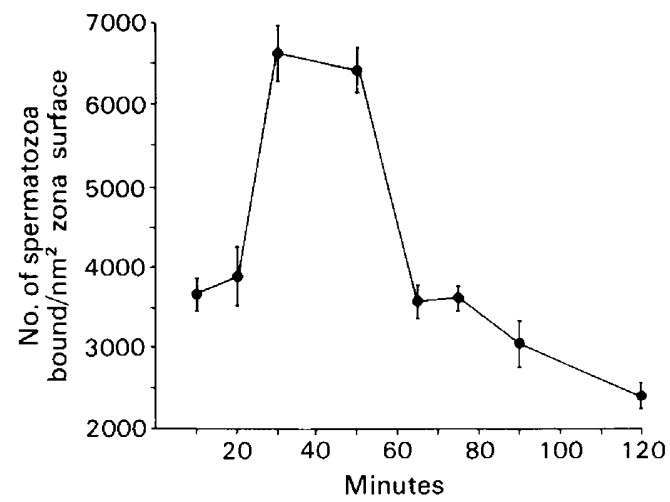

Text-fig. 1. Time course of sperm binding to the zona pellucida of unfertilized mouse eggs. Values are mean \pm s.e.m. for 10 eggs at each time.

rat (Gibco) or rabbit (Wellcome Laboratories) immunoglobulins. Following treatment with conjugated antiserum the eggs were washed 4 times and finally viewed under dark-field u.v.-blue illumination with a Leitz Ortholux II microscope equipped with a 50-W mercury lamp and a KP 490-mm interference filter, a secondary K530 green filter and a BG-38 red suppressor filter.

The intensity of the immunoprecipitation and immunofluorescence response was scored on a 4-point scale $(0,+,++$ and +++$)$ by two independent observers using coded samples.

\section{Production of antisera in rabbits}

Antisera were raised in male rabbits against mouse zonae pellucidae which had been solubilized by heating to $68^{\circ} \mathrm{C}$ (Cholewa-Stewart \& Massaro, 1972) in Dulbecco's phosphatebuffered saline ( $\mathrm{pH} \mathrm{7.2;} \mathrm{Flow} \mathrm{Laboratories)} \mathrm{or} \mathrm{by} \mathrm{exposure} \mathrm{to} \mathrm{low} \mathrm{pH}$ induced by 5.4 mm-adenosine-5-triphosphate in 0.9\% (w/v) $\mathrm{NaCl}$ (Brun \& Psychoyos, 1972). The immunization schedule involved a primary intramuscular injection of solubilized zona pellucida antigens (1500 solubilized zonae in $80 \mu \mathrm{l}$ medium) emulsified with Freund's complete adjuvant, an identical booster 14 days later and a final booster of antigen administered intravenously after a further 14 days.

The rabbits were bled from the marginal ear vein 7 and 9 days after the final injection.

\section{Production of antisera in rats}

Rats were actively immunized against mouse ovarian antigens extracted from the homogenized ovaries of randomly selected Q-strain female mice. Batches of 50 ovaries were homogenized in $0.9 \%(\mathrm{w} / \mathrm{v}) \mathrm{NaCl}$ at $0^{\circ} \mathrm{C}$ and centrifuged at $600 \mathrm{~g}$ for $10 \mathrm{~min}$. The protein content of the supernatant was determined by the method of Lowry, Rosebrough, Farr \& Randall (1951). A volume containing exactly $6 \mathrm{mg}$ protein (about $500 \mu \mathrm{l}$ ) was emulsified with an equal volume of Freund's complete adjuvant and injected at multiple subcutaneous sites into 8-9-week-old LH-strain female rats $(N=6)$. All of the rats had been shown, on the basis of vaginal cytology, to have had at least 3 normal oestrous cycles before the induction of immunity. Two booster injections were subsequently given at 14-day intervals incorporating an identical concentration of protein and Freund's incomplete adjuvant. Blood samples were collected at 2-week intervals from the tail vein during and after the completion of the immunization schedule to follow the evolution of the antibody titres.

Another 7 cyclic 6-8-week-old females were immunized against mouse serum proteins to control for the use of adjuvant and the non-specific antigens present in the ovarian extracts. The 
immunization schedule was identical to that employed for the mouse ovarian antigens, each injection incorporating $8 \mathrm{mg}$ serum protein.

In addition, another 6 rats were immunized against cumulus-free ova, each inoculation of antigen containing $750-1000$ eggs.

\section{Mating trials}

Two weeks after immunization against mouse ovarian antigens or serum proteins the rats were placed with males of proven fertility together with an untreated female which had previously been shown to have had at least 2 normal oestrous cycles on the basis of its vaginal cytology. Vaginal smears were subsequently taken daily from each female to monitor the occurrence of oestrous cycles, pseudopregnancies and pregnancies. The untreated female served as a continuous check on the fertility of the male. As soon as pregnancy could be diagnosed by palpation in the control female, she was replaced by another animal. If any of the male rats failed to mate with the control or immunized female at 3 consecutive oestrous periods, he was replaced.

When pregnancy was identified in an immunized animal she was removed to a littering cage and the mating trial was terminated.

\section{Absorption procedures}

The antisera raised against mouse ovarian antigens and cumulus-free mouse ova were absorbed with mouse liver, kidney and serum antigens (Tsunoda \& Chang, 1978) according to the following protocol. Equivalent weights $(8 \mathrm{~g})$ of mouse liver and kidney were separately homogenized at $0^{\circ} \mathrm{C}$ in $4 \mathrm{ml}$ of mouse serum diluted $1: 3$. The homogenates were then centrifuged at $600 \mathrm{~g}$, and the protein content of the supernatant determined by the method of Lowry et al. (1951). The protein concentration was subsequently adjusted to $15 \mathrm{mg} / \mathrm{ml}$ and 70 $\mu \mathrm{l}$ aliquots were transferred to $50 \times 6 \mathrm{~mm}$ test tubes and freeze-dried. To absorb the antisera, $500 \mu \mathrm{l}$ aliquots of serum were added to the freeze-dried antigen mixture and incubated for $1 \mathrm{~h}$ at $37^{\circ} \mathrm{C}$ followed by a further $14 \mathrm{~h}$ at $10^{\circ} \mathrm{C}$. After the incubations had been completed the tubes were centrifuged at $600 \mathrm{~g}$ for $10 \mathrm{~min}$, and the supernatant recovered for analysis by radial immunodiffusion.

Immunodiffusion plates were constructed using a $1 \cdot 3 \%$ solution of agarose in (Dulbecco's) phosphate-buffered saline ( $\mathrm{pH} 7 \cdot 2)$, into which wells with a capacity of about $20 \mu \mathrm{l}$ were cut. Samples of absorbed anti-zona antiserum, normal mouse serum, and aqueous extracts of liver or kidney (homogenized in Dulbecco's phosphate-buffered saline, $1 \mathrm{~g}$ tissue: $3 \mathrm{ml}$ medium) were added to each well and the plates developed in a moist chamber at $37^{\circ} \mathrm{C}$ for $72 \mathrm{~h}$. The gels were

\section{PLATE 1}

Fig. 1. Sperm binding to the zona pellucida of an unfertilized mouse egg. $\times 530$.

Fig. 2. Complete inhibition of sperm binding after the incubation of unfertilized mouse eggs in the presence of an antiserum directed against the zona pellucida. $\times 530$.

\section{PLATE 2}

Fig. 3. Formation of a precipitate on the surface of the mouse zona pellucida with antibodies raised against heat-solubilized zonae. $\times 250$.

Fig. 4. Absence of a precipitate on the surface of the mouse zona pellucida with antibodies raised against mouse serum proteins; only the oocyte is visible. $\times 250$.

Fig. 5. Labelling of mouse zona pellucida by indirect immunofluorescence employing an antiserum raised against heat-solubilized zonae pellucidae. $\times 250$. 

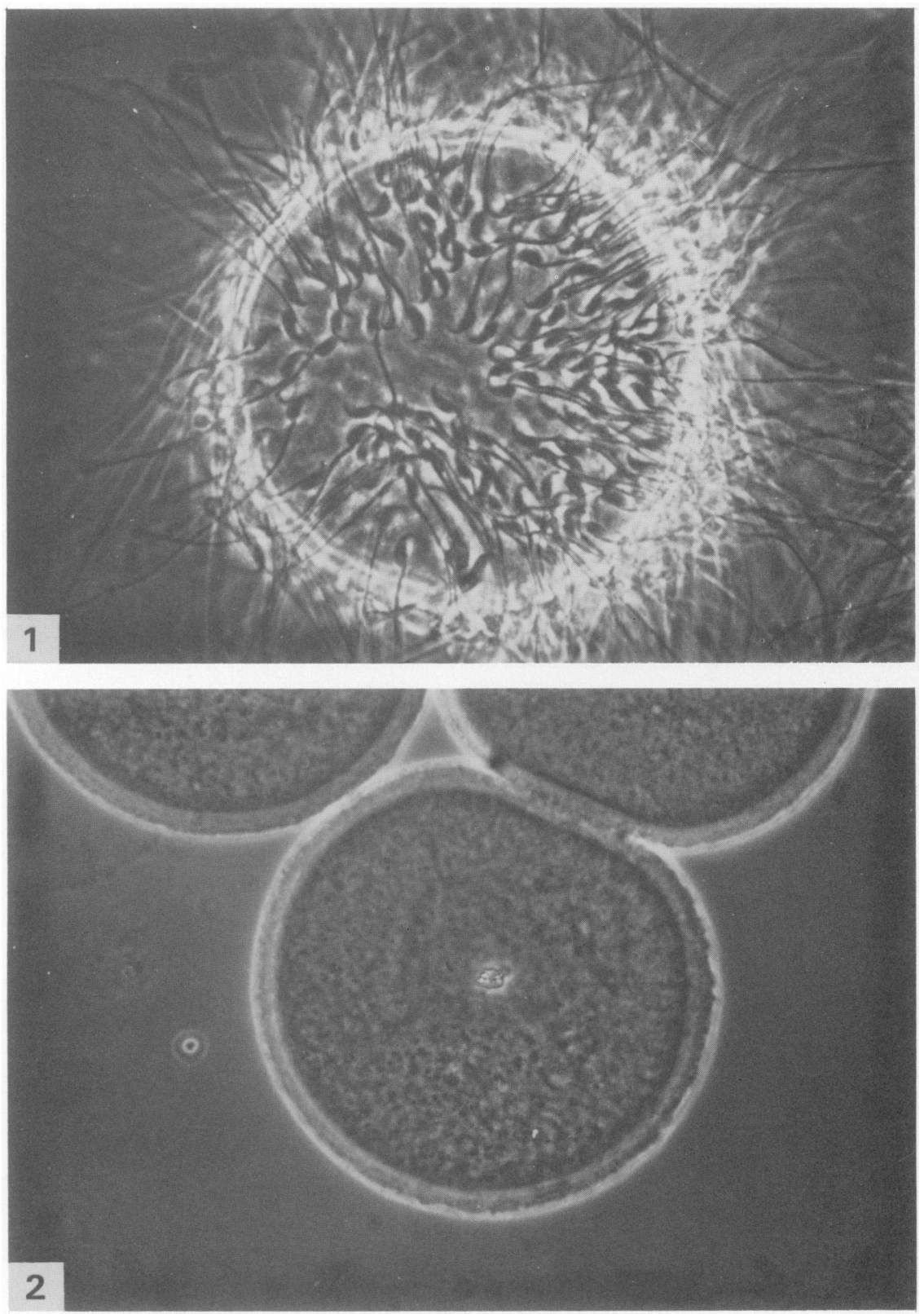
PLATE 2
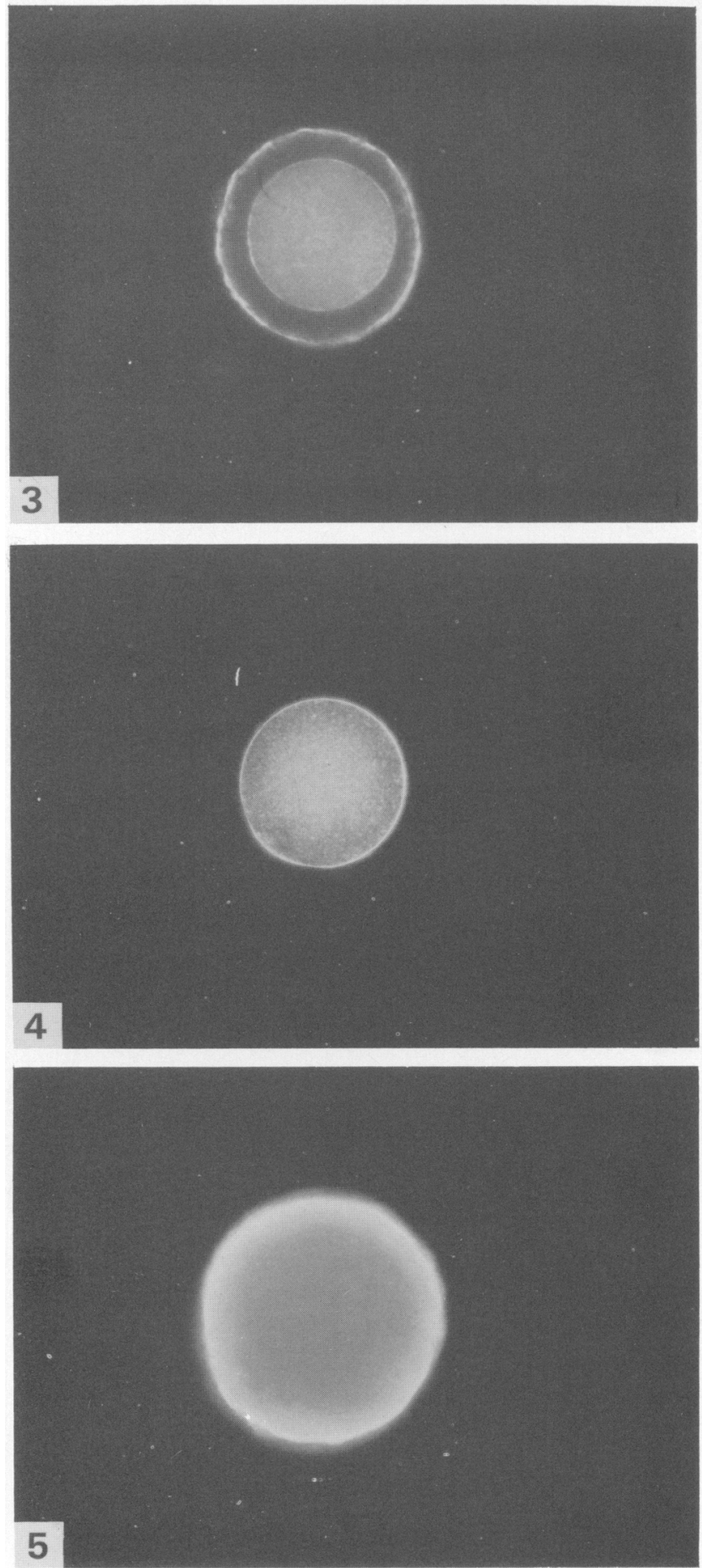

Downloaded from Bioscientifica.com at $04 / 26 / 2023$ 07:12:34AM 
subsequently washed for a further $72 \mathrm{~h}$ in $0.9 \%(\mathrm{w} / \mathrm{v}) \mathrm{NaCl}$, stained with Coomassie blue $(0.9 \%)$ and naphthalene black $(0.1 \%)$ in $7 \%$ acetic acid for 1-2 min and finally de-stained over a period of 3-4 days in 7\% acetic acid. The absorption procedure was repeated on each antiserum until no lines of cross-reactivity were observed with liver, kidney or serum antigens.

\section{Results}

Sperm binding capacity of the zona pellucida

Repeatability of determinations. The sperm binding capacity of the zonae pellucidae surrounding unfertilized mouse eggs was determined in 20 separate experiments using 8-11 oocytes in each. The within-assay coefficient of variation for these determinations ranged from 6 to $12 \%$, with a mean ( \pm s.e.m.) value of $9.5 \pm 0.42 \%$; the standard errors for each determination ranged from 2.4 to $4 \cdot 1 \%$ of the means. The between-assay variation was much larger, however, exhibiting a coefficient of variation of $20.8 \%$ and a range of values ( \pm s.e.m.) extending from $2750 \pm 95$ to $5286 \pm 141$ spermatozoa $/ \mathrm{mm}^{2}$ of zona surface. This interassay variation was presumably due to slight differences in the assay conditions and the fact that each determination was carried out using spermatozoa from a separate individual. Within-assay controls of untreated, unfertilized eggs were always included in each determination and any inhibition due to, for example, antibody or enzyme treatment was expressed as a percentage of this control.

Influence of complement and antibodies against mouse serum proteins. Antisera raised against mouse serum proteins did not induce the formation of an immunoprecipitate on the zona surface (Pl. 2, Fig. 4) but occasionally caused a diffuse immunofluorescent labelling of the zona, which was readily removed by prior absorption of the antiserum. Absorption of such antisera also modified their effects on the sperm binding capacity of the zona pellucida. The number of spermatozoa bound per $\mathrm{mm}^{2}$ zona surface increased significantly $(P<0.05 ; t$ test $)$ from a mean \pm s.e.m. $(n)$ of $3396 \pm 109(8)$ to $3900 \pm 174$ (7) following absorption of an antiserum raised against mouse serum proteins. All antisera raised against mouse ovarian antigens and cumulus-free mouse ova were therefore repeatedly absorbed (normally twice) before determination of their ability to suppress the sperm binding capacity of the zona pellucida.

To determine whether the presence of uncomplexed immuno-absorbent could interfere with the sperm binding assay a further series of 15 separate serum samples from the 6 serum-immunized animals was investigated. Following absorption (twice) of each antiserum with liver, kidney and serum antigens a mean ( \pm s.e.m.) inhibition of $6.2 \pm 2.0 \%$ relative to untreated unfertilized control ova was observed.

Table 1. Influence of complement on the ability of anti-zona antibodies to inhibit sperm binding in the mouse

\begin{tabular}{cccc}
\hline $\begin{array}{c}\text { Heat } \\
\text { inactivation } \dagger\end{array}$ & $\begin{array}{c}\text { Control } \\
\text { ova }\end{array}$ & $\begin{array}{c}\text { Treated } \\
\text { ova }\end{array}$ & $\begin{array}{c}\text { \% Inhibition } \\
\text { of binding }\end{array}$ \\
\hline+ & $4336 \pm 150(14)$ & $* * 2004 \pm 160(9)$ & 54 \\
- & $3224 \pm 192(9)$ & $* * 230 \pm 14(12)$ & 93 \\
+ & $4336 \pm 150(14)$ & $* 3725 \pm 207(8)$ & 14 \\
- & $3224 \pm 192(9)$ & $* * 1454 \pm 71(6)$ & 55 \\
+ & $4336 \pm 150(14)$ & $* * 2575 \pm 150(7)$ & 41 \\
- & $3183 \pm 116(14)$ & $* * 267 \pm 164(4)$ & 92 \\
\hline
\end{tabular}

Values are mean \pm s.e.m. for the no. of observations in parentheses.

$\dagger$ Of antiserum to mouse ovary extracts.

Significantly different from control values, ${ }^{*} P<0.05,{ }^{* *} P<0.001$ ( $t$ test). 
The presence of complement also appeared to have an effect on the ability of antisera to inhibit the binding of mouse spermatozoa to receptor sites on the zona pellucida (Table 1). Subsequently, therefore, all the antisera used were heat-inactivated by incubation at $56^{\circ} \mathrm{C}$ for 30 $\min$ before analysis.

Influence of antisera against mouse zona antigens. Antisera raised against mouse ovarian antigens, cumulus-free mouse oocytes and solubilized zonae pellucidae all contained antibodies which bound avidly to mouse zonae pellucidae, forming a precipitate on the zona surface (Pl. 2, Fig. 3) and exhibiting an intensely positive immunofluorescence response (PI. 2, Fig. 5). When unfertilized mouse eggs were incubated with these antisera for $30 \mathrm{~min}$ the subsequent binding of spermatozoa to the zona pellucida was suppressed compared with untreated control ova ( $\mathrm{Pl}$. 1, Fig. 2; Table 2).

Table 2. Inhibition of sperm binding to the mouse zona pellucida by anti-zona antibodies

\begin{tabular}{cccc}
\hline & \multicolumn{2}{c}{$\begin{array}{c}\text { No. of spermatozoa bound } / \mathrm{mm}^{2} \\
\text { zona surface }\end{array}$} & $\begin{array}{c}\text { \% Binding } \\
\text { inhibition }\end{array}$ \\
\cline { 2 - 4 } Antiserum & Control serum & Test serum & \\
\hline $\begin{array}{c}\text { Rabbit anti-heat } \\
\text { solubilized zona }\end{array}$ & $5045 \pm 191(8)$ & $1184 \pm 85(6)$ & 77 \\
$\begin{array}{c}\text { Rabbit anti-ATP } \\
\text { solubilized zona }\end{array}$ & $5165 \pm 145(9)$ & $1873 \pm 391(7)$ & 64 \\
$\begin{array}{c}\text { Rat anti-cumulus } \\
\text { free ova }\end{array}$ & $5045 \pm 191(8)$ & $254 \pm 84(9)$ & 95 \\
$\begin{array}{c}\text { Rat anti-ovarian } \\
\text { extract }\end{array}$ & $4696 \pm 194(8)$ & $537 \pm 52(8)$ & 89 \\
\hline
\end{tabular}

Values are mean \pm s.e.m. for the no. of observations in parentheses.

All test serum values were significantly different from control values, $P<0.001$ ( $t$ test).

To determine the consistency of this suppression, independent analyses were made on 9 samples of antiserum (5 raised against mouse ovarian antigens and 4 against cumulus-free mouse ova) exhibiting a range (8-100\%) of inhibitory activity. These duplicate determinations were made without the knowledge of sample identity and the correlation observed $(r=0.979)$ indicates good agreement between the results obtained in separate assays (Table 3).

Table 3. Repeatability of sperm binding determinations in separate assays

\begin{tabular}{cccc}
\hline & \multicolumn{2}{c}{$(\%)$ Binding inhibition } & \\
\cline { 2 - 3 } Antiserum & 1st determination & 2nd determination & $\begin{array}{c}\text { Difference } \\
(\%)\end{array}$ \\
\hline To mouse ovarian & & & \\
extract 1 & 48 & 54 & 6 \\
2 & 8 & 14 & 6 \\
3 & 14 & 8 & 6 \\
4 & 100 & 100 & 0 \\
5 & 100 & 100 & 0 \\
To cumulus-free & & 36 & 14 \\
mouse ova 1 & 22 & 34 & 11 \\
2 & 45 & 18 & 2 \\
3 & 16 & 11 & 4 \\
4 & 15 & & $5.4 \%$ \\
\hline
\end{tabular}


Serial dilutions of 4 antisera gave sigmoid dilution curves typical of antigen-antibody interactions (Text-fig. 2). The slopes of the separate dilution curves were parallel and linear over a range extending from at least 20 to $80 \%$ inhibition of binding. The suppressive activity exhibited by these antisera was rapidly diluted out and irrespective of whether these results were expressed as \% inhibition of binding (Text-fig. 2a) or as the number of spermatozoa bound per unit area of zona surface (Text-fig. 2b), a return to control values was observed within 20-30 dilution steps.

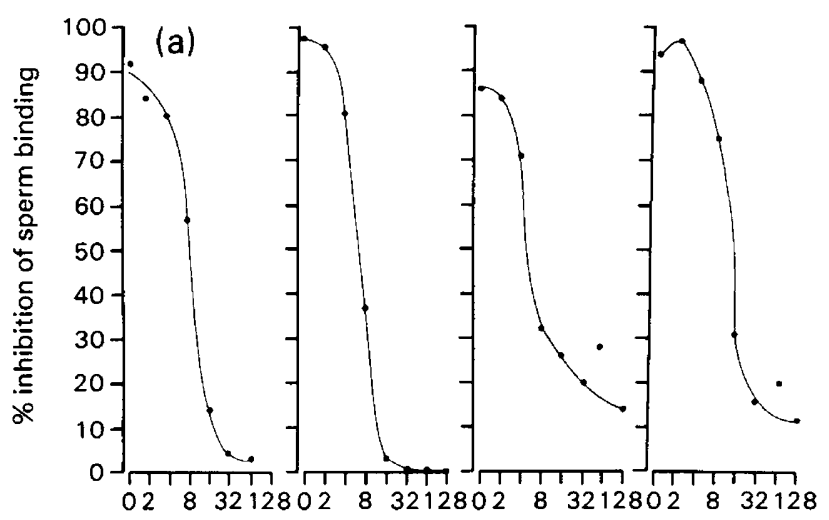

Dilution of antiserum

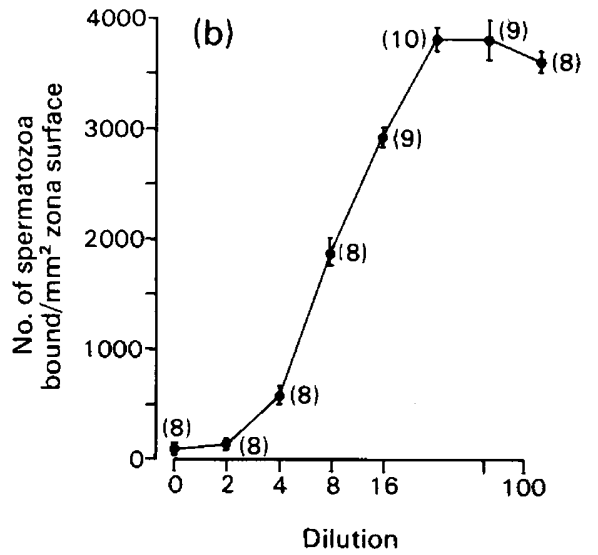

Dilution

Text-fig. 2. Influence of serially diluted antisera raised against cumulus-free ova on the sperm binding capacity of mouse zonae pellucidae: (a) results for 4 antisera, (b) results for a single antiserum.

Correlation between immunofluorescence, immunoprecipitation and sperm binding titres. Text-figure 3 illustrates the relationships between the sperm binding titre, immunofluorescence and immunoprecipitation responses for a series of 366 serum samples obtained from 12 immunized rats. The results indicate the existence of highly significant correlations $(P<0.001)$ between all three methods of antibody detection regardless of whether the antisera were raised

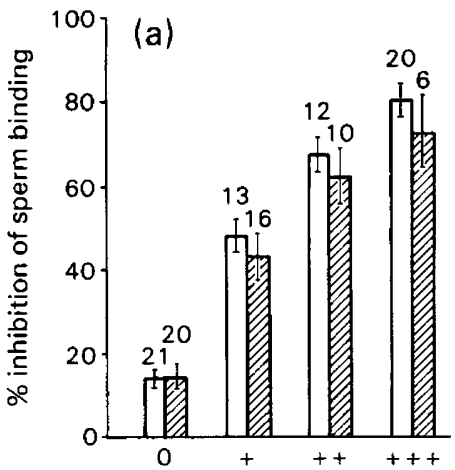

Immunoprecipitation

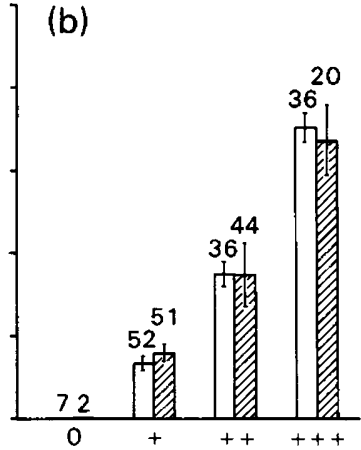

Immunofluorescence

Text-fig. 3. Correlations between the ability of anti-zona antisera to inhibit sperm binding and induce (a) the formation of a precipitate on the zona surface and (b) labelling of the zona by indirect immunofluorescence. In (a) $0=$ samples of antisera in which antibodies against the zona could be detected by indirect immunofluorescence, but which failed to form a precipitate at the zona surface. In (b) $0=$ samples taken from animals before the appearance of detectable anti-zona antibody titres. Values are mean \pm s.e.m. for the no. of observations indicated at the top of each column. 
against cumulus-free mouse oocytes or mouse ovarian antigens. The correlations between immunoprecipitation and sperm binding for antisera raised against cumulus-free ova and ovarian extract were $0.968(n=66)$ and $0.977(n=52)$, respectively, while the equivalent correlations between immunofluorescence and sperm binding were $0.978(n=131)$ and 0.988 $(n=117)$.

\section{Anti-zona antibody titres and fertility in rats}

Immunization against mouse serum proteins. This technique was not successful in rendering treated animals infertile (Table 4). All 7 animals became pregnant, 6 of the 7 conceiving at the first mating with a mean litter size of 8.1 . The remaining animal was removed to a littering cage after exhibiting a prolonged period ( 23 days) of dioestrus following the detection of spermatozoa in the vaginal smear, but no young were observed during the ensuing 4 weeks. This animal immediately conceived a litter of 10 young when re-introduced to its male partner. The male rats paired with these immunized animals impregnated 10 untreated control females during the course of the experiment with a mean litter size of 9.7 , which was not significantly different $(P>$ 0.05 ) from that of the treated animals. None of the absorbed blood samples recovered from these animals contained anti-zona antibody activity when analysed by immunoprecipitation, ( $\mathrm{Pl}$. 2, Fig. 4), immunofluorescence and sperm binding techniques.

Table 4. Breeding records of rats immunized against serum proteins or mouse ovarian antigens between the initiation of the mating trial and conception

\begin{tabular}{|c|c|c|c|c|c|c|c|}
\hline Immunogen & $\begin{array}{c}\text { Animal } \\
\text { no. }\end{array}$ & $\begin{array}{c}\text { No. of } \\
\text { oestrous } \\
\text { periods }\end{array}$ & $\begin{array}{c}\text { No. of } \\
\text { matings }\end{array}$ & $\begin{array}{l}\text { No. of } \\
\text { non-pregnant } \\
\text { cycles }\end{array}$ & $\begin{array}{c}\text { No. of } \\
\text { pseudo- } \\
\text { pregnancies }\end{array}$ & $\begin{array}{l}\text { No. of } \\
\text { litters }\end{array}$ & $\begin{array}{c}\text { Duration } \\
\text { of } \\
\text { infertility } \\
\text { (months) }\end{array}$ \\
\hline Serum & $\begin{array}{l}52 \\
56 \\
49 \\
62 \\
63 \\
35 \\
36\end{array}$ & $\begin{array}{l}2 \\
2 \\
2 \\
2 \\
1 \\
2 \\
1\end{array}$ & $\begin{array}{l}1 \\
2 \\
1 \\
1 \\
1 \\
1 \\
1\end{array}$ & $\begin{array}{l}1 \\
0 \\
1 \\
1 \\
0 \\
1 \\
0\end{array}$ & $\begin{array}{l}0 \\
1 \\
0 \\
0 \\
0 \\
0 \\
0\end{array}$ & $\begin{array}{r}7 \\
10 \\
6 \\
2 \\
5 \\
16 \\
11\end{array}$ & $\begin{array}{l}{ }^{*} \overline{0.75^{*}} \\
- \\
- \\
- \\
-\end{array}$ \\
\hline Ovary & $\begin{array}{l}44 \\
66 \\
71 \\
34 \\
65 \\
47\end{array}$ & $\begin{array}{r}8 \\
4 \\
24 \\
35 \\
22 \\
1\end{array}$ & $\begin{array}{r}7 \\
1 \\
14 \\
12 \\
12 \\
1\end{array}$ & $\begin{array}{l}3 \\
3 \\
0 \\
0 \\
2 \\
-\end{array}$ & $\begin{array}{r}3 \\
0 \\
14 \\
12 \\
10 \\
-\end{array}$ & $\begin{array}{r}5 \\
4 \\
- \\
- \\
-\end{array}$ & $\begin{array}{c}2.00 \\
- \\
10.25 \\
11.5 \\
10 \cdot 5 \\
0.3 \dagger\end{array}$ \\
\hline
\end{tabular}

Immunization against mouse ovarian antigens. Of the 6 animals immunized against mouse ovarian antigens, 2 eventually became pregnant and the others stayed infertile for the remainder of their life-span despite repeated matings (Table 4). One of the animals (No. 44) which did eventually conceive showed a rapid rise in antibody titre during the immunization schedule which peaked at $90 \%$ inhibition of binding and then fell rapidly. This animal mated 7 times as titres declined and the last of these matings, which took place when antibody concentration reached undetectable levels according to the sperm-binding and immunoprecipitation assays, resulted in a pregnancy and the ultimate birth of 5 normal healthy young. Conception in this animal, therefore, took place when anti-zona antibodies were still present and detectable by indirect immunofluorescence although the titre was apparently inadequate to suppress 
fertilization. Shortly after the birth of the young the antibody titres exhibited a temporary resurgence before declining to basal levels once more (see Text-fig. 2b of Aitken et al., 1981).

The second animal which conceived following immunization against mouse ovarian antigens failed to develop an antibody titre above $63 \%$ inhibition of sperm binding. After the termination of the immunization schedule the antibody titres stabilized at this level for a period of 5 weeks during which mating and conception took place. Antibody titres fell during pregnancy but showed a temporary elevation shortly after the birth of the litter. By 6 months after the induction of immunity the circulating concentration of antibody had fallen to undetectable levels according to the immunoprecipitation and sperm binding assays although the indirect immunofluorescence procedure still registered antibody presence (Text-fig. 4a).

In the animals that did not conceive despite repeated matings (Nos 71, 34 and 65) the antibody titres stayed higher for longer. In Rat 71 , the titres rose rapidly at the end of the immunization schedule to a maximum of $90 \%$ inhibition of binding and remained elevated for a period of 5 months. Anti-zona antibodies were still detectable thereafter by indirect immunofluorescence although the titre fluctuated between 7 and $40 \%$ binding inhibition. The few matings which did occur during this final 6-month period did not result in any pregnancies (See Text-fig. 2a of Aitken et al., 1981). Rat 34 exhibited a similar rapid rise in titre following the induction of immunity but antibody concentration remained elevated for 9 months before returning to basal levels. After this time anti-zona antibodies could still be detected by indirect immunofluorescence but the titre fluctuated between 0 and $20 \%$ inhibition of sperm binding. Despite the low concentrations of antibody, the occasional matings observed during this later period were not successful in establishing pregnancy (Text-fig. 4b). Rat 65 exhibited a short-lived rapid rise in titre to $96 \%$ inhibition of binding, following the first antigen booster and a second rise to $83 \%$ binding inhibition following the final injection. Antibody titres then progressively declined to reach basal levels 5 months after the completion of the immunization schedule. During the subsequent 6 months antibody titres remained low, between 9 and $25 \%$ inhibition of binding, but the antifertility effect was retained (Text-fig. 4c). Rat 47 was killed 9 days after mating had taken place when antibody titres had risen to $85 \%$ inhibition of binding, and immunofluorescence and immunoprecipitation were maximal. Histological examination revealed that although ovulation had occurred and apparently normal corpora lutea were present in the ovaries there was no evidence of embryos in the uterus.

Rats 44 and 66 which became pregnant after the anti-zona antibody titres had waned were subsequently given a booster injection of $6 \mathrm{mg}$ ovarian protein emulsified with Freund's incomplete adjuvant. The animals were subsequently bled at weekly intervals and, 14 days after the booster injection, were paired with fertile males and killed $48 \mathrm{~h}$ after finding spermatozoa in the vaginal smears to determine whether fertilization had occurred. One of the serum-immunized animals (No. 52) was similarly given a booster injection of $8 \mathrm{mg}$ mouse serum protein emulsified with Freund's incomplete adjuvant and subsequently killed, together with an untreated control female, $24 \mathrm{~h}$ after mating. In the untreated-control and serum-immunized animals $12 / 12$ and 6/7 of the eggs recovered were fertilized, respectively, and no circulating anti-zona antibodies could be detected by the immunofluorescence, immunoprecipitation and sperm-binding tests. In addition none of the eggs recovered from these animals exhibited a precipitate on the outer zona surface when examined under dark field illumination. In Rat 44, however, there was a sudden rise in anti-zona antibody titre to give $50 \%$ inhibition in the sperm binding test (see Text-fig. $2 \mathrm{~b}$ of Aitken et al., 1981). All of the 13 eggs recovered possessed a pronounced precipitate on the surface of the zona pellucida and, with one exception, all were unfertilized and fragmenting. The exception was an apparently normal 2 -cell egg which nevertheless exhibited a pronounced zona precipitate under dark-field illumination. Rat 66 exhibited a rapid rise in antibody titre to a peak of $63 \%$ binding inhibition and an equally precipitous decline (Text-fig. $4 \mathrm{a}$ ). When mating took place the titre had fallen to $9 \%$ binding inhibition and 8 out of 10 eggs recovered had been fertilized; all of the eggs recovered had a light precipitate at the zona surface. 

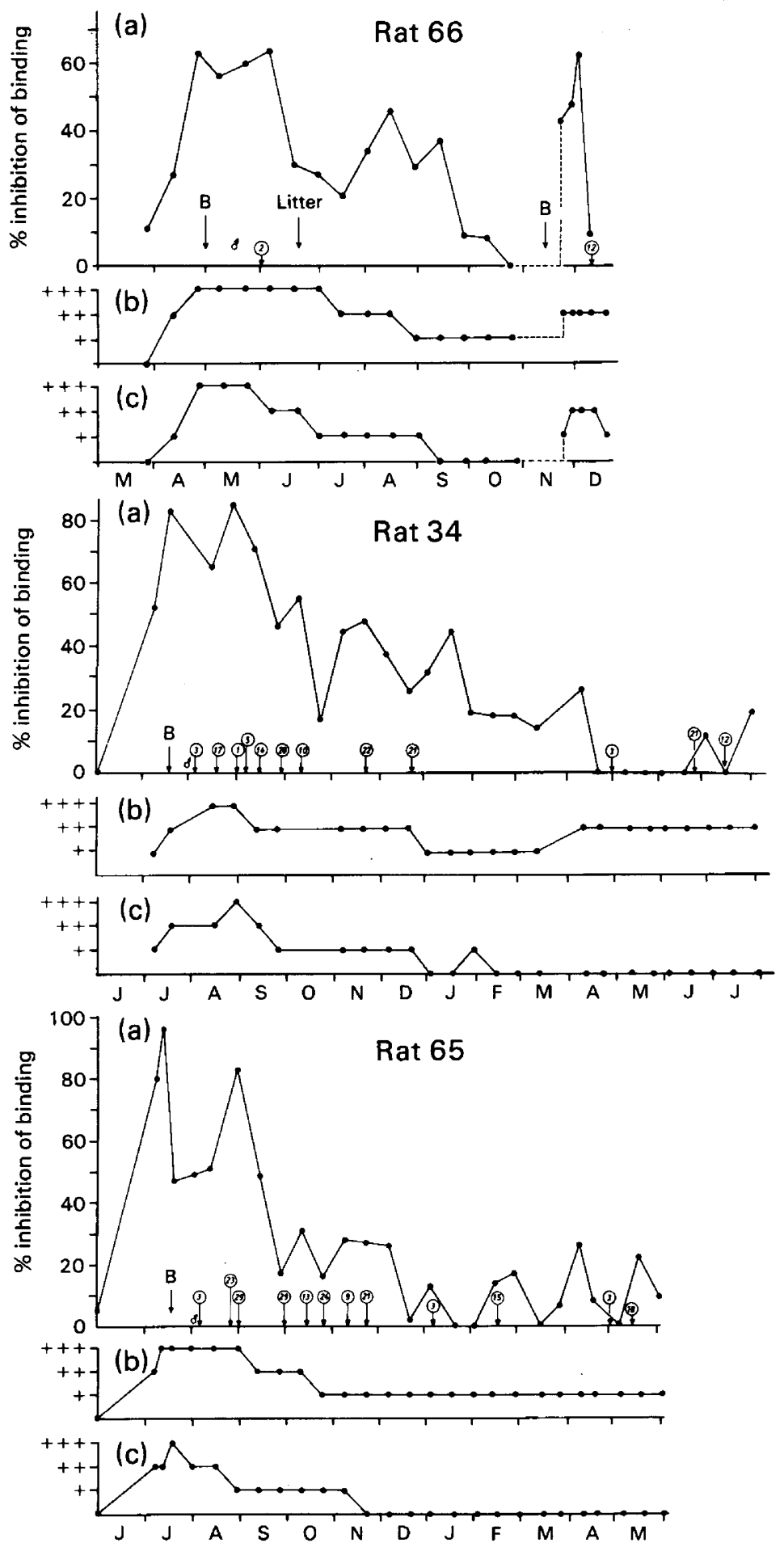

Text-fig. 4. Anti-zona antibody titres in Rats 66,34 and 65 actively immunized with an aqueous extract of mouse ovarian tissue and exhibiting normal fertility (Rat 66) or permanent infertility (Rats 34 and 65). $B=$ final injection of the immunization schedule; $\delta^{*}=$ introduction of fertile male; $Q)$ = spermatozoa detected in vaginal smear on day of month indicated. For each rat, $(\mathrm{a})=$ sperm binding assay, (b) = immunofluorescence and (c) = immunoprecipitation. 
During the course of these experiments, the fertility of the males used in the study was continuously monitored. The males paired with the 3 animals experiencing long-term infertility (Nos 71, 34 and 65) impregnated 11, 10 and 11 control females, respectively, over the same period and each of these females conceived at the first mating. The absence of pregnancies in the immunized animals was therefore not due to any deficiencies on the part of the males.

\section{Discussion}

This study defines conditions which give highly repeatable estimates of the sperm binding capacity of the zona pellucida. This procedure should find application in experiments designed to investigate such topics as the nature of the sperm binding sites on the zona pellucida (Bleil \& Wassarman, 1980a), the interactions between the ovum and the zona pellucida during the post-fertilization block to polyspermy (Inoue \& Wolf, 1975), and in the estimation of anti-zona antibody titres. The loss of binding activity exhibited by the zonae of unfertilized mouse eggs after exposure to spermatozoa for $60 \mathrm{~min}$ emphasizes the need to carry out such determinations under carefully controlled conditions. This reduced binding may be due to the destruction of sperm receptor sites by acrosin originating from acrosome-reacted spermatozoa (Gwatkin et al., 1977b). The influence of complement on sperm-binding activity is more difficult to explain, although it is possible that complement absorbed onto the surface of the zona exerts a toxic effect upon attaching spermatozoa. Low levels of non-specific interference with binding activity were also observed in the presence of antisera raised against serum proteins both before and after absorption, indicating a loss of specificity in the assay when anti-zona antibody titres are low. When anti-zona antibody titres are high, however, the assay is extremely sensitive, giving a rapid change in sperm binding inhibition for a small change in antibody concentration. The results obtained with this sperm binding assay exhibited a good correlation with the immunoprecipitation and immunofluorescence responses given by the same antisera, although only the sperm binding test gave truly quantitative results. The indirect immunofluorescence procedure appeared to be the most sensitive indicator of antibody presence because in several of the actively immunized animals this technique detected anti-zona antibodies when both the sperm binding assay and the immunoprecipitation assays failed to register significant activity. Indirect immunofluorescence was also found to be the most sensitive assay procedure by Tsunoda, Sugie \& Mori (1979) who compared immunoprecipitation, zona dissolution, indirect immunofluorescence and in-vitro fertilization as methods for the measurement of anti-zona antibody titres. These authors also observed a good correlation between the ability of an antibody to deposit a precipitate at the zona surface and its capacity to inhibit fertilization in vitro. In view of the results obtained in the present study it seems likely that the abilities of an antibody to form a zona precipitate, inhibit sperm binding and block fertilization are causally related; the deposition of antibody complexes at the zona surface presumably occludes the sperm binding sites and thereby inhibits fertilization. The sperm binding assay might be preferred to in-vitro fertilization as a method of assessing antibody titre, since the former gives a direct objective measurement of those properties of an anti-zona antiserum that are responsible for its infertility activity.

The active immunization of rats with mouse ovarian antigens appears to induce a variable period of infertility in association with the production of anti-zona antibodies. The proportion of animals conceiving at their first mating was significantly lower in the zona-immunized group (1/6) than in the serum-immunized controls $(6 / 7 ; P<0.05)$, untreated control females housed with the same males as the zona-immunized animals $(37 / 38 ; P<0.001)$ or a group of unselected control females housed with separate males $(119 / 120 ; P<0.001)$ when analysed by the $\chi^{2}$ test. Similarly the percentage of matings resulting in conception was significantly lower in the zona-immunized group (2/47) than in the serum-immunized animals $(7 / 8 ; P<0.001)$, untreated control females housed with the same males as the zona-immunized group $(38 / 39$; $P<0.001)$ and a group of unselected control females housed with separate males $(120 / 121 ; P<$ 
$0.001)$. There was no evidence for a seasonal influence on the fertility of our rat colony that might have confounded the results obtained in the mating trials; 59/60 unselected control females conceived at their first mating between November and February compared with 60/60 from May to September, values which are not significantly different $\left(P>0.05 ; \chi^{2}\right.$ test).

The fact that the zona pellucida is the most antigenic compound of the ovary (Sacco \& Shivers, 1973; Oikawa \& Yanagimachi, 1975) and the existence of extensive cross-reactivity between rat and mouse zona pellucida antigens (Aitken \& Richardson, 1980) presumably accounts for the induction of infertility in this active immunization model. The mechanism by which infertility is achieved is probably through the deposition of antibody complexes at the zona surface and the subsequent occlusion of the sperm binding sites. This hypothesis is supported by the presence of a precipitate on the zona surface of ova recovered from actively immunized rats but not the appropriate controls. The extent of this precipitate appeared to correlate well with the degree to which fertilization had been inhibited and the inhibitory activity of the blood serum in the sperm binding assay. One of the eggs recovered from Rat 44 was an apparently normal 2-cell embryo despite the presence of a precipitate at the zona surface. While parthenogenetic activation of this egg cannot be ruled out, this result, in conjunction with the information obtained from Rat 66 (which conceived a litter of 4 young in the presence of significant antibody titres), indicates that the complete suppression of fertility requires the presence of high antibody titres. This conclusion is in keeping with the inefficient mechanism of action of anti-zona antibodies which appears to involve the masking of receptors-for-spermatozoa by steric hindrance rather than direct interaction with the binding sites (Aitken \& Richardson, 1981). With the exception of Rat 66 the fertility of the remaining animals was suppressed during the first 6 months of the mating trial by antibody titres ranging from 5 to $90 \%$ inhibition of sperm binding. The only animal in which antibody titres fell to $0 \%$ binding inhibition during this initial period immediately conceived (Rat 44). Beyond this 6-month period the infertility effect was sustained even when antibody titres did fall to levels at which no sperm binding inhibition was observed. At this stage of reproductive life the presence of low anti-zona antibody titres in the immunized animals, together with a natural decline in fertility due to ageing and a corresponding reduction in mating frequency, would presumably have enhanced the suppression of fertility.

The variation in antibody titres between the immunized animals might be due to differences in the immunological responsiveness of the animals and to variations in the amount of zona antigen contained within each preparation of mouse ovarian extract. Although the immunizing injections were equalized with respect to total protein content it was not possible to determine the proportion of this figure made up of zona material.

An unexpected finding during the course of the study was the elevation in antibody titre observed after parturition in the 2 animals exhibiting a temporary period of infertility. The fact that this rise was recorded by the sperm binding assay but not by the immunofluorescence technique is presumably due to the fact that the former is a more sensitive, quantitative assay. It is possible that these post-partum changes in antibody titre reflect the release of the maternal immune system from state of suppression during pregnancy (Morton, Hegh \& Clunie, 1974).

These studies confirm earlier reports by Gwatkin, Williams \& Carlo (1977a) that infertility without overt adverse side effects can be induced by active immunization techniques involving the use of heterologous cross-reacting zona antigens, and indicate for the first time that permanent sterility can result from such procedures. The future of this research now lies in the fractionation and biochemical characterization of the zona pellucida antigens (Dunbar, Wardrip \& Hedrick, 1980; Dunbar \& Raynor, 1980; Bleil \& Wassarman, 1980b) and the evaluation of the isolated components in an active immunization model similar to the one described.

We thank Mr D. Doogan, Ms J. Winchester and Ms N. Cunningham for their help with the animals. 


\section{References}

Aitken, R.J. \& Richardson, D.W. (1980) Immunization against zona pellucida antigens. In Immunological Aspects of Reproduction and Fertility Control, pp. 173-201. Ed. J. P. Hearn. MTP Press Ltd, Lancaster.

Aitken, R.J. \& Richardson, D.W. (1981) Mechanism of sperm binding inhibition by anti-zona antisera. Gamete Res. 4, 41-47.

Aitken, R.J., Rudak, E.A., Richardson, D.W., Dor, J., Djahanbahkch, O. \& Templeton, A. (1981) The influence of anti-zona and anti-sperm antibodies on sperm-egg interactions. J. Reprod. Fert. 62, 597-606.

Austin, C.R. \& Braden, A.H.W. (1956) Early reactions of the rodent egg to spermatozoa penetration. $J$. exp. Biol. 33, 358-365.

Bleil, J.D. \& Wassarman, P.M. (1980a) Mammalian sperm-egg interaction: identification of a glycoprotein in mouse egg zonae pellucidae possessing receptor activity for sperm. Cell 20, 873-882.

Bleil, J.D. \& Wassarman, P.M. (1980b) Structure and function of the zona pellucida: identification and characterization of the proteins of the mouse oocytes zona pellucida. Devl Biol. 76, 185-202.

Brun, J.L. \& Psychoyos, A. (1972) Dissolution of the rat zona pellucida by acidified media and blastocyst viability. J. Reprod. Fert. 30, 489-491.

Cholewa-Stewart, J. \& Massaro, E.J. (1972) Thermally induced dissolution of the murine zona pellucida. Biol. Reprod. 7, 166-169.

Dunbar, B.S. \& Raynor, B.D. (1980) Characterization of porcine zona pellucida antigens. Biol. Reprod. 22, 941-954.

Dunbar, B.S., Wardrip, N. \& Hedrick, J.L. (1980) Isolation, physiochemical properties and the macromolecular composition of the zona pellucida from porcine oocytes. Biochemistry, N.Y. 19, 256-365.

Gwatkin, R.B.L. (1977) Fertilization Mechanisms in Man and Mammals. Plenum Press, New York.

Gwatkin, R.B.L., Williams, D.T. \& Carlo, D.J. (1977a) Immunization of mice with heat-solubilized hamster zonae: production of anti-zona antibody and inhibition of fertility. Fert. Steril. 28, 871-877.

Gwatkin, R.B.L., Wudi, L., Hartree, E.F. \& Fink, E. (1977b) Prevention of fertilization by exposure of hamster eggs to soluble acrosin. J. Reprod. Fert. 50, $359-361$.

Hartmann, J.F. \& Gwatkin, R.B.L. (1971) Alteration of sites on the mammalian sperm surface following capacitation. Nature, Lond. 234, 479-481.

Hartmann, J.F, Gwatkin, R.B.L. \& Hutchison, C.F. (1972) Early contact interactions between mammalian gametes in vitro: evidence that the vitellus influences adherence between sperm and zona pellucida. Proc. natn. Acad. Sci. U.S.A. 69, 2767-2769.

Inoue, M. \& Wolf, D.P. (1975) Fertilization associated changes in the murine zona pellucida: a time sequence study. Biol. Reprod. 13, 546-551.

Jilek, F. \& Pavlok, A. (1975) Antibodies against mouse ovaries and their effect on fertilization in vitro in the mouse. J. Reprod. Fert. 42, 377-380.

Lowry, O.H., Rosebrough, N.J., Farr, A.L. \& Randall, R.J. (1951) Protein measurements with the Folinphenol reagent. J. biol. Chem. 193, 265-275.

Morton, H., Hegh, V. \& Clunie, G.J.A. (1974) Immunosuppression detected in pregnant mice by the rosette inhibition test. Nature, Lond. 249, 459.

Oikawa, T. \& Yanagimachi, R. (1975) Block of hamster fertilization by anti-ovary antibody. J. Reprod. Fert. 45, 487-494.

Sacco, A.G. \& Shivers, C.A. (1973) Localization of tissue specific antigens in the rabbit ovary, oviduct and uterus by the fluorescent antibody technique $J$. Reprod. Fert. 32, 415-420.

Shivers, C.A., Dudkiewicz, A.B., Franklin, L.E. \& Fussell, E.N. (1972) Inhibition of sperm egg interaction by specific antibody. Science, N.Y. 178, 12111213.

Tsunoda, Y. \& Chang, M.C. (1976a) Reproduction in rats and mice isoimmunised with homogenates of ovary, testis with epididymis or sperm suspension. $J$. Reprod. Fert. 46, 379-382.

Tsunoda, Y. \& Chang, M.C. (1976b) Effect of anti-rat ovary antiserum on the fertilization of rat, mouse and hamster eggs in vivo and in vitro. Biol. Reprod. 14, 354-361.

Tsunoda, Y. Chang, M.C. (1977) Further studies of antisera on the fertilization of mouse, rat and hamster eggs in vivo and in vitro. Int. J. Fert. 22, 129-139.

Tsunoda, Y. \& Chang, M.C. (1978) Effects of antisera on fertilization of mouse, rat and hamster egg. Biol. Reprod. 18, 468-474.

Tsunoda, Y., Sugie, T. \& Mori, J. (1979) Quantitative determination of titres of antizona serum. $J$. exp. Zool. 207, 315-320. 